\title{
Interaction of Relationship between Job Motivation with Teacher Innovativeness in Improving Education
}

\author{
Henny Suharyati \\ The Lecturer of Pakuan University, Bogor, Indonesia \\ E-mail: enny.suharyati@unpak.ac.id
}

\begin{abstract}
The purpose of this research is to examine the correlation between dependent variables such as: teacher's job motivation with an independent variable, innovativeness, of Paud Teachers. The survey is conducted by taking a sample of 144 teachers who had graduated from The Teachers Training College by proportional random sampling technique at Paud teachers in Bogor, West Java, Indonesia. The research used a Sequential Explanatory Design Mixed Method. First the quantitative research is conducted then followed by the qualitative research to support the research has more thoroughly comprehensive output. The quantitative research portrays that there is a very significant positive correlation between the dependent variable with the independent variable. This positive correlation is supported by the qualitative research which states if the dependent variable such as a motivation is higher so independent variable, the innovativeness, will increase too. The quantitative research concludes that: there is a positive correlation between motivation with innovativeness and there are other factors which have a positive correlation in increasing innovativeness. This conclusion is supported by the qualitative research which shows the strongest influence of motivation on innovativeness.
\end{abstract}

Keywords: job motivation, teacher's innovativeness, paud teachers

\section{INTRODUCTION}

Early childhood education is the basic capital for subsequent children's education. The demand for the quality of educational graduates is increasingly urgent in line with the development of society and the world of work and the unavoidable changes in global competition. The quality of educational graduates can be achieved if there is synergistic cooperation between schools, communities, and the world of work as users of education output. Schools as a qualified human resource printing institution must work effectively and efficiently as one of the criteria for school productivity. The productivity of the school is closely related to the school's resources, one of which is qualified and innovative teachers. Teachers have an important role in producing highquality graduates. Teachers or educators of early childhood are generally the same as the learning guardians, facilitators, tutors who have the following characteristics or traits: a charismatic figure, the ability to design a learning program, able to organize and manage the class effectively, efficiently, adult figure who can consciously educate, teach, guide and make teachers as professions that require special skills.

The fact, it can be said that the innovation of Paud teachers is still low and not optimal. It is suspected that there are irresponsible practices in teaching and learning process, as the current flourishing is teaching CALISTUNG
(Reading, Writing and Counting) in early childhood. This is not in accordance with Government Regulation No.137 Thun 2014, Article 10 stating that: the scope of development according to the age level of the child includes aspects of religious and moral values, physical motor, cognitive, language, social-emotional, and art as contained in Appendix I Which is an integral part of this Ministerial Regulation.

1) The religious and moral values referred to in paragraph (1) include the ability to recognize the value of the religion held, worship, honest, helper, polite, respectful, sportive, maintain personal hygiene and environment, know religious holidays, And tolerant of the religion of others.

2) Physical-motor as referred to in paragraph (1) shall include:

a. Rough motorics, including the ability of body movement in a coordinated, flexible, balanced, agile, locomotor, non-locomotor, and follow the rules;

b. Smooth motor, including the ability and flexibility of using fingers and tools to express oneself in various forms; and

c. Health and safety behaviour, including weight, height, head circumference according to age and ability to live clean, healthy, and caring for its safety. 
Cognitive as referred to in paragraph (1) includes:

1) Learning and problem solving involves solving simple problems in everyday life in a flexible and socially acceptable way and applying knowledge or experience in a new context;

2) Logical thinking, including differences, classifications, patterns, berinsiatif, plan, and know cause and effect; and

3) Symbolic thinking, including the ability to recognize, mention, and use the concept of numbers, recognizing letters, and able to represent various objects and imagination in the form of images.

1) The language referred to in paragraph (1) shall consist of:

a. Understanding receptive language, including the ability to understand stories, orders, rules, enjoy and appreciate reading;

b. Express the language, including the ability to ask questions, answer questions, communicate orally, retell the known, learn pragmatic language, express feelings, ideas and desires in the form of graffiti; and

c. Literacy, including an understanding of the relationship of form and the sound of letters, imitate letters, and understand the word in the story.

2) The social-emotional as referred to in paragraph (1) includes:

a. Self-awareness, consisting of showing self-ability, self-knowing and self-control, and being able to adapt to others;

b. Responsibility for self and others, including the ability to know their rights, to obey the rules, to selfregulate, and to be responsible for their behaviour for the good of others;

c. Prosocial behaviour, including the ability to play with peers, understanding feelings, responding, sharing, and respecting the rights and opinions of others, being cooperative, tolerant, and behaving decently. (1) The art referred to in paragraph (1) includes the ability to explore and express oneself, imagine with movements, music, drama, and various other art fields (painting, fine arts, crafts), and able to appreciate art, , As well as drama.

Observing the ministry regulations mentioned above, the achievement of early childhood development is more focused on the development of strong children's character. Achievement of cognitive aspects in symbolic thinking includes the ability to recognize, mention, and use the concept of numbers, recognizing letters, and able to represent various objects and imagination in the form of images. Early childhood is not required to read, write and count as well as the current practice of learning. It is clear that teachers have not been up to innovation to develop appropriate learning models for early childhood and in accordance with Ministerial regulations. Simple educational innovation can be interpreted as innovation in the field of education. Whereas the innovation of a teacher is very important in improving the quality of education, achieving an effective, efficient and conducive education in increasing the toughness of the students facing the challenges of life in the future.

The factors that allegedly inhibit and lead to low innovation of teachers include several things such as: management of the institution paud itself such as planning, managing, monitoring and evaluating of teachers has not been applied maximally. Unclear vision and norms of Paud organization. Teacher work motivation plays an important role in teacher innovation because of internal drive to develop, innovate in making new ideas.

Based on the background and the results of problem identification, then the formulation of the problem is as follows: Is there any relationship between teacher work motivation with teacher innovation?

The word innovation based on its etymology is taken from the Latin "innovare", meaning "to make something new". Innovative is a behavior or action that demonstrates the level of innovation that has already been done. In this case, innovativeness shows a change in one's behavior and actions and not just his mind. Everyone is judged to have innovative potential, though not all can develop or utilize its full potential. Some experts present the following theories of innovation below.

John R. Schermerhorn, James G. Hunt, Richard N. Osborn, Mary Uhl-Bien states: innovation is the process of creating a new idea and then proposing it. Innovation is a means of developing creative ideas applied in everyday life, ideally innovation is a practice that contributes to the improvement of consumer services and organizational poductivity. There are several ways to look at innovation. Here innovation is considered as a process, separating the product from the innovation process, and recording all the tensions from the beginning of the development of the idea until its implementation (2010: 376-379).

The concepts of the same innovations have also been suggested by Wood, Wallace, Zeppane, Schermerhorn, and Hunt as follows: explaining that innovation is the process of creating new ideas and practicing them. Innovation is a way in which creative ideas can be found daily in the form of new goods or services that can satisfy consumers or new systems and services that help organizations better. There are three dimensions that are emphasized: a) Product innovation with indicators: 1) creating new ideas, 2) improving products/services; B) Process innovation with its indicators: 1) better way of making something; C) Innovation of product/service implementation with indicators: 1) marketing the first product/service, 2) the existence of products / services that is the creation of new ideas or improving old products / services into new forms (2001: 611-614).

Robbins (2003: 571-572) states the same thing that: "Innovation is a new idea applied to initiating or improving a product, process, or service." Innovation is a new idea applied to starting or improving a product, process or service. Greenberg and Baron (2008: 568-572) reinforce Robbins's opinion by stating that: "Innovation is the process 
of making change into something that has been so By introducing something new. Bessant and Tidd (2011: 28-33) states that: "Innovation is the process of translating ideas into more benefits and using products, processes and services the new one. Osborne and Brown (2005: 119-145) also emphasize that innovation is the introduction of newness into a system and is associated with the adoption of new ideas. Also explained there are two related factors concerning process innovation and transformation.

Based on the above description of the theory mentioned that innovation is the activity of creating ideas, renewing old products or services, need a process, create new service products or services. Innovativeness is how innovation is done. Thus it can be synthesized that keinovatian is a behavior or action in creating ideas, updating existing products or services through a process and implementing new products or services in the form of marketing services.

In educational organizations, teachers' innovation is the behavior or action of teachers in creating ideas or updating existing ideas in teaching and learning activities such as making lesson plans, learning models, media and tools used in learning, assessment systems and classroom management Require the implementation process of the learning product results and socialize it to all citizens of learning.

The dimensions and indicators are as follows:

1) Dimensions of product innovation consisting of indicators: 1) creation of new ideas, 2) improvement of products or services.

2) Dimensions of process innovation consisting of indicators: 1) ways of making things, 2) implementation of the findings.

3) Dimensions of product implementation innovation consisting of indicators: 1) enhancing the attractiveness of new products or services, 2) socializing new products or services.

The basic understanding of motivation is the internal state of the organism that drives it to do something. The word "motive" is defined as the effort that drives someone to do something. Motives can be said as the driving force from within and within the subject to perform certain activities in order to achieve a goal. Even the motif can be interpreted as an internal condition (kesigapan). Starting from the word motive, then the motivation can be interpreted as a driving force that has become active. Motives become active at certain times, especially when the need to achieve goals is felt. (Sudirman: 2008: 73).

Schunk, Pintrich, Meece (2008: 4-5) states that the term motivation derived from the Latin word "movere" means "move". The idea of movement is reflected from the idea of reason as motivation as something that keeps us moving, keeping our performance and helping us accomplish the task. Motivation is a process shown by directed activities to achieve the purpose of being initiated and maintained.

Deckers (2010: 1) states that motivation is a picture of a process that encourages one to perform an action. Motivation can come from the internal self described as a biological and psychological variables, and if coming from outside an external person for example can take the form of an incentive or purpose of someone to do an action.

Greenberg and Baron (2008: 248-253) cite the theory of Maslow that defines motivation as a set of processes that arise, directly within a person and maintain his behavior in achieving goals. Similarly, Robins defines motivation as follows: motivation is a process that calculates the intensity, direction and persistence of individuals achieve a goal. The factors are as follows: 1) intensity: how one tries (effort), 2) direction: organizational advantage, 3 ) perseverance.

Spector (2008: 200) defines motivation is an internal state in a person associated with a particular behavior. One perspective mentions the relationship of motivation with direction, intensity, persistence behavior at the same time. Direction refers to the choice of specific behavior of a large number of existing behaviors. Intensity refers to the number of attempts by a person to do his job. Persistence refers to a continuous relationship. In other perfectives, motivation requires consciousness with the drive to achieve the same goals, human desires, needs or impulses.

Colquit, Lepine and Wessor (2009: 546-551) define motivation as a series of energetic forces coming from within and outside of employees, initiating work effort, and determining its direction, its intensity and endurance. Related factors are: 1) internal strength, 2) self-confidence, 3) external forces, 4) purpose of giving.

Based on some of the above description of the theory, it can be synthesized that the teacher's work motivation is an energetic drive from within himself as well as the influence from outside himself that encourages activity and gives strength in determining the intensity and endurance to achieve the goal of Paud School. The dimensions and indicators of teacher work motivation are:

1) The intrinsic dimension consists of indicators: 1) the drive to work hard, 2) the drive to achieve the work, 3) the spirit of achieving success,

2) Extrinsic dimensions consisting of indicators: 1) collaboration with personnel in the work environment, 2) awards from the environment, 3) leadership support.

\section{METHOD}

There are many combinations of research, but this research uses combination method of Sequential Explanatory Design Mixed Method. This research model is also named as the "sequence of proof" model because there is an evidence that the next sequence is deepening. First done a quantitative research first so the result is clear and measurable. Then followed by the second stage of qualitative research so that the results are more focused. This method is used when researchers are not satisfied with the results of the first study using quantitative methods, so it needs to be deepened by qualitative methods.

The data collection and analysis of the two methods were carried out separately, but made concurrent. (Sugiyono, 2005: 38-39) The study population consisted of PAUD Formal (Private Kindergarten) teachers residing in 6 subdistricts in Bogor city. The sample was obtained by 
proportional random sampling technique as many as 225 teachers and with Slovin formula obtained a sample of 144 teachers.

\section{RESULT AND DISCUSSION}

The functional relationship between $\mathrm{X}$ and $\mathrm{Y}$ can be presented in the form of regression equation as follows: $\hat{Y}=$ $51,70+(0,582) X$. Based on calculation result of regression significance obtained $F$ value count $=33,389$ while $F$ Table $(\alpha=0,05)=3,91$ and F Table $(\alpha=0.01)=6.81$. This shows that the relationship between teachers' work motivation variable $(\mathrm{X})$ with teacher innovation $(\mathrm{Y})$ is significant. The strength of the relationship between teacher work motivation variables with teacher innovation is shown by correlation coefficient by $=0.4363$. Based on the calculation results obtained the count $=5.778$ while tTable $=1.645$. This means that the correlation coefficient between teacher work motivation and teacher innovation is significant. The coefficient of determination between teacher work motivation and teacher innovation is $R y^{2}=0,1903$. This means that $19,037 \%$ of teachers 'innovative variance can be strengthened by teachers' work motivation. The hypothesis stating that there is a positive relationship between teacher work motivation with teacher innovation is acceptable, meaning that the higher the motivation of teacher work, the higher the level of teacher innovation.

The coefficient of determination between work motivation and teacher innovation is $\mathrm{Ry} 1^{2}=0,1903$. This means that $19.03 \%$ of teachers' innovation is the result of the workings of teacher work motivation, while $80.97 \%$ is contributed by other variables that have a relationship with improvement of teacher innovation. The findings obtained in this study indicate that teacher work motivation is the delivery of messages and information exchange between individuals that are direct and face-to-face, and generate feedback so that messages can be understood and delivered properly.

This is consistent with the theory put forward by Jerald Greenberg citing Maslow's theory that defines motivation as a set of processes that arise, directly within a person and retains his behaviour in achieving the goal. Robins defines motivation as follows: motivation is a process that calculates the intensity, direction and perseverance of individuals achieve a goal. The motivation of work is to be one factor that can be improved so that teachers can optimize its function in carrying out its duty to achieve the best educational goals. By increasing the motivation of teacher work, the higher the value of the teacher's innovation in working in his school.

The results of previous studies have also proven that the motivation of teacher work has a positive relationship with innovation, one of them is Cinzia Battistella research, Fabio Nonino which concludes the existence of related relationship between work motivation and innovation by making network pattern of motivation and identify role dimension, is potential. The result of analysis shows that there are 4 factors ranging from $87.3 \%$ of the variation. The conclusion shows that these four factors have an effect with the coefficient of 0.8 and this indicates a high correlation.

These results indicate that the research hypothesis accepted, which means there is a very significant relationship between teacher work motivation with teacher innovation. This means that the better the teacher's work motivation the higher the value of teacher's innovation, and vice versa, the lower the teacher's work motivation the lower the innovation of the teacher. With the discovery of facts and data in the analysis of this study further supports previous research on the existence of a positive relationship between teacher work motivation with teacher innovation. Similarly, based on qualitative research results interview analysis, FGD, observation and documentation at three schools Paud Formal (Kindergarten) Private in the city of Bogor, it can be seen that there is a tendency relationship between teacher work motivation with teacher innovation. This shows the strengthening of the quantitative research of hypothesis testing which states that there is a functional relationship between teacher work motivation and teacher's innovation with regression is very significant and shows that every improvement of teacher work motivation score will improve teacher's innovation. From the findings obtained in this 2stage research it can be seen that the motivation of teacher work which is the impulse from within the teacher to carry out the task and its function in achieving the goal of Paud school will able to give its contribution in improving the innovation of the teacher.

\section{CONCLUSION}

There is a positive relationship quantitatively reinforced by the results of qualitative research on variables: There is a positive relationship between teacher work motivation with teacher innovation. This positive relationship is reinforced by qualitative research results. Thus the higher the teacher's work motivation, the higher the level of teacher innovation.

Efforts to improve teacher innovation through teacher work motivation.

1) The encouragement from within the teacher to work hard in carrying out his work and be optimistic in targeting yourself to achieve better work from before, more optimize performance in doing the work and increase the sense of love of a teacher's work in education.

2) The encouragement of teachers to achieve success and improve achievement in achieving their work by highlighting the initiative and always conditioned themselves to be nice and positive in accordance with the functions and duties, have a high spirit to create a sense of security and comfortable in carrying out daily tasks.

3) The encouragement to improve the ability of teachers to collaborate with all the citizens of the school in the environment and carry out the cooperation between the personal well regarding the physical and psychological factors so as to create togetherness in achieving the mission objectives Paud school.

4) The recognition and appreciation and sensitivity to the performance of teachers by giving the maximum 
appreciation of the loyalty, performance and achievements achieved in the form of awards and opportunities as broadly associated with increased promotion and higher education, so that teacher career path can run well and in accordance with The prevailing system.

5) Increase support from headmaster leaders to always encourage teachers to keep the task well, keep each other and remind to always be positive to face all developments so that the system of education in school can run according to its purpose.

\section{REFERENCES}

Aan Komariah \& Cepi Triatna. (2005). Visionary Leadership: Menuju Sekolah Efektif, Jakarta: PT Bumi Aksara.

Andriopoulos, Constantine, Dawson, Patrick. (2011). Managing Change, Creativity and Innovation, London: SAGE Publication Ltd.

Astridya Paramita dan Lusi Kristiana. (2013). Teknik Focus Group Discussion dalam Penelitian Kualitatif, Buletin Penelitian sistem Kesehatan - Vol. 16.No.2 April 2013 : hh. 117-127.

Battistella, Cinzia, Nonino, Fabio. (2011). Exploring the impact of motivations on the attraction of innovation roles in open innovation web-based platforms, San Fransisco Airport Marriot Waterfront, RWTH Aachen University, www.rwth-aachen.de, 16-19 November 2011.

Bungin, H.M. Burhan. (2007). Penelitian Kualitatif: Komunikasi, Ekonomi, Kebijakan Publik, dan Ilmu Sosial lainnya,Jakarta : Prenada Media Group.

Champoux, Joseph E. (2003). Organizational Behaviour-Essential Tenets.Thomson South-Western.

Coulcit, Jason A., Lefine, Jefrey A., Wessor, Michel J. (2009). Organizational Improving Performance and Commitment in the Workplace, New York : McGraw Hill,Irwin.

Creswell, John W. \& Clark, Vicki L. (2007). Plano, Designing and Conducting Mixed Methods Research, USA : Sage Publication, Inc.

Deckers, Lambert. (2010). Motivation: Biological, Psychological, and Environmental, New Jersey: Allyn \& Bacon, Pearson Education, Inc.

Djajadi, Iqbal, Sosiologi Industri, Modul 3, (Jakarta: Universitas),http://pustaka.ut.ac.id/puslata/gmp/images/SOS14314.jp $\mathrm{g}$

Greenberg, Jerald, Baron, Robert A. (2008) Behavior in Organizations, New Jersey : Pearson International Inc.
Gibson, James L. Gibson, dkk. (2006). Organization Behavior, Structure, Processes, Twelfth Edition, Singapore: McGraw-Hill, 2006

Hurt, H.T., Joseph, K., \& Cook, C.D. (1977). Scales fotr the Measurement of Innovativeness, Human Communication Research, 4, 2003

Iqbal Djajadi, Sosiologi Industri, Modul 3, (Jakarta: Universitas), http://pustaka.ut.ac.id/puslata/gmp/images/SOS14314.jpg.

Ivancevich, James H. Donelly,Jr. Robert Konopaske. (2012). Organizations Behavior, Structure, Processes, Fourtteenth Edition ,Singapore : The McGraw-Hill Companies.

Kinicki, Angelo, Williams, Brian K. (2008). Management : A Practical Introduction, New York : MacGraw-Hills Companies, Inc., 2008

Kreitner, Kinicki, Organizational Behavior, New York : McGraw Hill Companies, Inc.

Luthan, Fred. (2012). Organizational Behavior, Twelfth Edition, Singapore : McGraw-Hill, Inc.

MacShane, Stephen L., Glinow, Mary Ann von. (2010). Organizational Behavior, New York : McGraw Hill Irwin.

Martinis Yamin H. \& Jamilah Sabri Sanan. (2013). Panduan Paud :Pendidikan Anak Usia Dini, Ciputat : Gaung Persada Pers Group.

Osborne, Stephen P., Brown, Kerry. (2005). Managing Change and Innovation in Public Service Organizations,New York : Routledge.

Rita Retnowati. (2007). Metodologi Penelitian, Bogor: Universitas Pakuan.

Richard L. Daft. (2010). New Era of Management, ninth edition,Canada : Nelson Education, Ltd.

Robbins, Stephen P. Judge, Timothy A. (2013). Organizational Behavior,USA : Pearson Education Ltd., 2013

Sheen, Ng Yu, Singh, Sharan Kaur Garib, Jayasingam, Sharmila, (2012) The Journal of Human Resource and Adult Learning, Vol. 8, Num. 2, December 2012.

Spector, Paul.E., Industrial and Organizational Psycology: Research and Practise, USA : John Wiley \& Sons, Inc.

Sudirman. A.M. dkk. (2008). Interaksi dan Motivasi Belajar Mengajar, Jakarta: PT. Raja Grafindo Persada

Sugiyono. (2009). Metode Penelitian Pendidikan : Pendekatan Kuantitatif, Kualitatif, R \& D, Bandung : Alfabeta.

(2011). Metode Penelitian Kombinasi (Mixed Methods),Bandung :Alfabeta.

Tim Penyusun. (2007). Buku Panduan Rencana Kegiatan Harian Taman Posyandu, Jakarta : Direktorat Paud.

Wood, Wallace, Zeppane, Schermorhorn, Hunt, Osborn. (2001). Organizational Behaviour: A Global Perspective,Sydney : John Wiley \& Sons Australia, Ltd.

Yeşil, Salih \& Kaya, Ahmet. (2012). The Role of Organisational Culture on Innovation Capability : An Empirical Study, International Journal of Information Technology and Business Management, 29th 2012 Vo.6 No. 